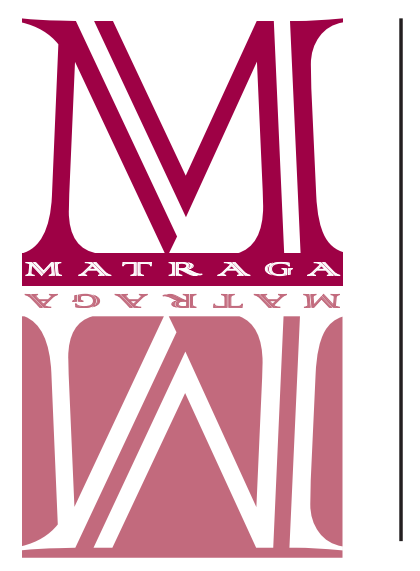

\title{
A moralização da morte no Theatrum Sacrum de Antônio Vieira
}

\author{
Ana Lúcia Machado de Oliveira \\ Universidade do Estado do Rio de Janeiro/CNPq \\ https://orcid.org/0000-0001-6149-6239
}

\section{RESUMO}

O presente artigo traz algumas reflexões preliminares sobre o lugar da morte e o florescimento do macabro no imaginário social entre os séculos XVI e XVII, a partir do diálogo com as obras de Delumeau, Arriès, Mâle e Chanu, dentre outros. Em seguida, examina-se a grande difusão da imagem do corpo na cultura seiscentista, que traz como corolário o papel de destaque da anatomia, a qual transcende o âmbito das práticas médicas e invade outros campos do saber, revestindo-se de sentidos metafóricos, tal como na expressão "anatomia moral", muito empregada na época.

Para abordar o lugar do púlpito na difusão do conceito de morte propagado pelo catolicismo no século XVII, será analisada a obra sermonística do jesuíta Antônio Vieira, tendo como foco a sua construção de um memento mori a partir da retomada do lugar-comum bíblico de que o homem é pó e ao pó voltará, tão reciclado por pregadores e poetas do período. Esse tema escritural é desenvolvido nos três sermões vieirianos da Quarta-Feira de Cinzas, que são discutidos na parte final deste texto.

PALAVRAS-CHAVE: Antônio Vieira; Morte; Sermões; Retórica.

\section{The Moralization of Death in Antônio Vieira's Theatrum Sacrum}

\section{ABSTRACT}

Initially this article delineates the role of death and the proliferation of the macabre in the social imagination between the 16th and 17th centuries, based on the works of Delumeau, Arriès, Mâle and Chanu, among others. Secondly, it examines the widespread diffusion of human body images in the 17th century culture as well as the prominent role of anatomy, which transcended the scope of medical practices, adopting metaphorical meanings.

The aforementioned topics pave the way to understanding the relevance of the pulpit in the dissemination of the Catholic Church's concept of death, which can be identified in the sermonistic work of the Jesuit Antônio Vieira. The main focus of the present article is an analysis of Vieira's construction of a memento mori from the resumption of the biblical commonplace that man is dust and to the dust will return. This scriptural theme is developed in the three Ash Wednesday ecclesiastical sermons composed by Vieira, which are discussed in the final section of this paper.

KEYWORDS: Antônio Vieira; Death; Sermons; Rhetoric. 


\section{Oh não aguardes que a madura idade}

Te converta em flor, essa beleza

Em terra, em cinza, em pó, em sombra, em nada.

GREGórIO DE MATOS

$\mathrm{P}$ ara examinar a configuração da morte nos sermões do jesuíta seiscentista Antônio Vieira, tema central deste artigo, parto de dois campos de investigação que serão aqui colocados em diálogo.

Inicialmente, com as lentes lapidadas por Jean Delumeau (1983, p. 44), em seu relevante trabalho de estabelecimento de uma história cultural do pecado, destaco que, para compreender o lugar da morte no imaginário social entre os séculos XIV e XVII, é importante situá-la no interior de dois grandes conjuntos explicativos: em primeiro lugar, o longo processo de aculturação religiosa e de culpabilização que, partindo dos monastérios, atingiu, por ondas concêntricas, camadas cada vez mais amplas da população. Em outras palavras, um aspecto que permite compreender melhor a função e o rosto dados à morte pela civilização europeia dessa época é o relevo constante atribuído ao contemptus mundi - ou seja, ao desprezo pela vida mundana, material -, o qual, ultrapassando o espaço monástico, invadiu um espaço cultural mais abrangente. Outro ponto importante para o campo investigado é o profundo pessimismo, resultado de grandes tensões acumuladas, que dominou os espíritos da época, entre o tempo da denominada peste negra e o fim das guerras de religião.

Delumeau interroga a expressão "familiaridade com a morte", tão frequentemente empregada pelos historiadores para caracterizar os comportamentos humanos desse período. De fato, é notável a constante encenação da morte que então se produz, facilmente perceptível em textos e em imagens da época. Como se sabe, o tema da salvação constitui, então, o leitmotiv do discurso religioso, que leva o homem a pensar incessantemente na morte a fim de evitar os pecados que poderiam conduzi-lo ao inferno. Assim, a meditação sobre a morte e o convite ao exame de consciência são elementos solidários de um mesmo discurso. Significa dizer que a Igreja representou um papel essencial no abandono de uma maneira mais "natural" de viver a morte, como conclusão de um ciclo vital, "propondo a meditação sobre esse término como eficaz método de pedagogia moral” (DELUMEAU, 1983, p. 50). Não se deve, portanto, esquecer que foi o Cristianismo que, se não inventou totalmente a "morte de si mesmo" - para empregar a bem sucedida expressão cunhada por Philippe Arriès (1977, p. 29), a qual enfatiza a ruptura entre o fado de cada um e o destino coletivo da espécie - , pelo menos a ampliou às dimensões de uma civilização. Dialogando com a investigação de Arriès, Delumeau traz o foco para os predecessores das grandes vias macabras dos séculos XV e XVI, destacando que desprezo do mundo, dramatização da morte e insistência na salvação pessoal emergiram em conjunto.

Expresso em palavras ou em imagens, era recorrente na época o convite ao homem para se olhar em um espelho que lhe remetesse a imagem de seu futuro cadáver. É a mesma lição que ensinam todos os corpos dissecados ou em vias de decomposição que a arte europeia se com- 
praz em figurar, com uma espécie de realismo provocador, entre o fim do século XIV e o início do XVII. Conforme parece evidente, em tal perspectiva, habituar-se à morte é obrigatoriamente saber olhar o macabro. Desse modo, a menção ao crânio e ao túmulo figura em grande parte dos textos da época bem como em pinturas e ilustrações abundantemente difundidas. Na sintética formulação do historiador cuja reflexão sigo aqui de perto: "Não há caminho para a salvação a não ser através dos cemitérios. O cristão deve viver no pensamento da morte" (1983, p. 393).

Desse modo, pode-se concluir, ainda com Delumeau, que a referida "familiaridade" com a morte é, antes, forçada, voluntarista, resultante de um grande esforço sobre si mesmo que o fiel deve exercer seguindo os ditames da ortodoxia católica. Em vez de familiar, a morte é uma passagem perigosa que só será ultrapassada ao preço de uma vigilância de toda a vida. Diante dela, portanto, é necessário ter medo; como corolário desse ditame, todas as evocações são úteis - cinzas e putrefação, agonia, trombetas do Juízo e visões do inferno - para impedir que esse medo seja dominado, mantendo-o vivo, ameaçador. Com tal finalidade, verifica-se a operação de uma "pedagogia traumatizante" (a expressão é de Delumeau, 1983, p. 638), centrada no reconhecimento de que a morte tem grande eficácia "convertedora". Sumariando tal processo, pode-se afirmar que a expansão do discurso monástico operou a transformação do medo natural da morte em um medo religioso do juízo final.

Importa ainda destacar que tal discurso sobre a morte, oriundo dos monastérios, é renovado no final do XVI e início do XVII por religiosos, especialmente os jesuítas, que foram em grande parte responsáveis pelo novo florescimento do macabro que se observa especialmente no século XVII. Émile Mâle (1932, p. 208) atribuiu uma importância decisiva aos Exercícios espirituais inacianos no recrudescimento do macabro cristão que acompanhou a Contrarreforma. Estava na lógica da pastoral católica desse tempo apoiar-se no pensamento da morte e propor concretamente o rosto desta aos fiéis, como forma de reforçar o temor e obter a persuasão para uma vida verdadeiramente cristã; assim, crânios e ossos são frequentemente oferecidos pela iconografia a um público mais amplo do que aquele que os textos intitulados "Preparações para a morte", leitura comum na época, poderiam atingir. Daí a presença quase obsedante dos principais temas do contemptus mundi no interior de considerações cristãs sobre a morte, mesmo quando redigidas por laicos: o corpo não tem importância, a vida é apenas um sonho, frequentemente um pesadelo... De todo modo, a morte permanece no centro da pedagogia religiosa, em todos os níveis de operação desta.

É significativo, a esse respeito, que o macabro induzido pelo contemptus mundi tenha provocado no século XVII, em todo o espaço católico, uma floração de pinturas e de gravuras consagradas ao tema das vanités ou vanitas (figura 1) Aos sermões de Bossuet e de Antônio Vieira, aos numerosos poemas garantindo que a vida é um "sonho" e que tudo se desfaz "em terra, em cinza, em pó, em sombra, em nada" - como o de Gregório de Matos aqui usado como epígrafe - responde a Madalena meditando sobre um crânio, do pintor Georges de La Tour (figura 2), dentre um grande número de composições picturais que associam o crânio, a ampulheta e uma flor, por exemplo. Além disso, na época, os santos são frequentemente apresentados meditando diante de um crânio, o qual funcionava como uma espécie de "emblema da santidade" (MÂLE, 1932, p. 210). 
FIGURA 1. Vanitas, de Antonio de Pereda (1670 ca.)

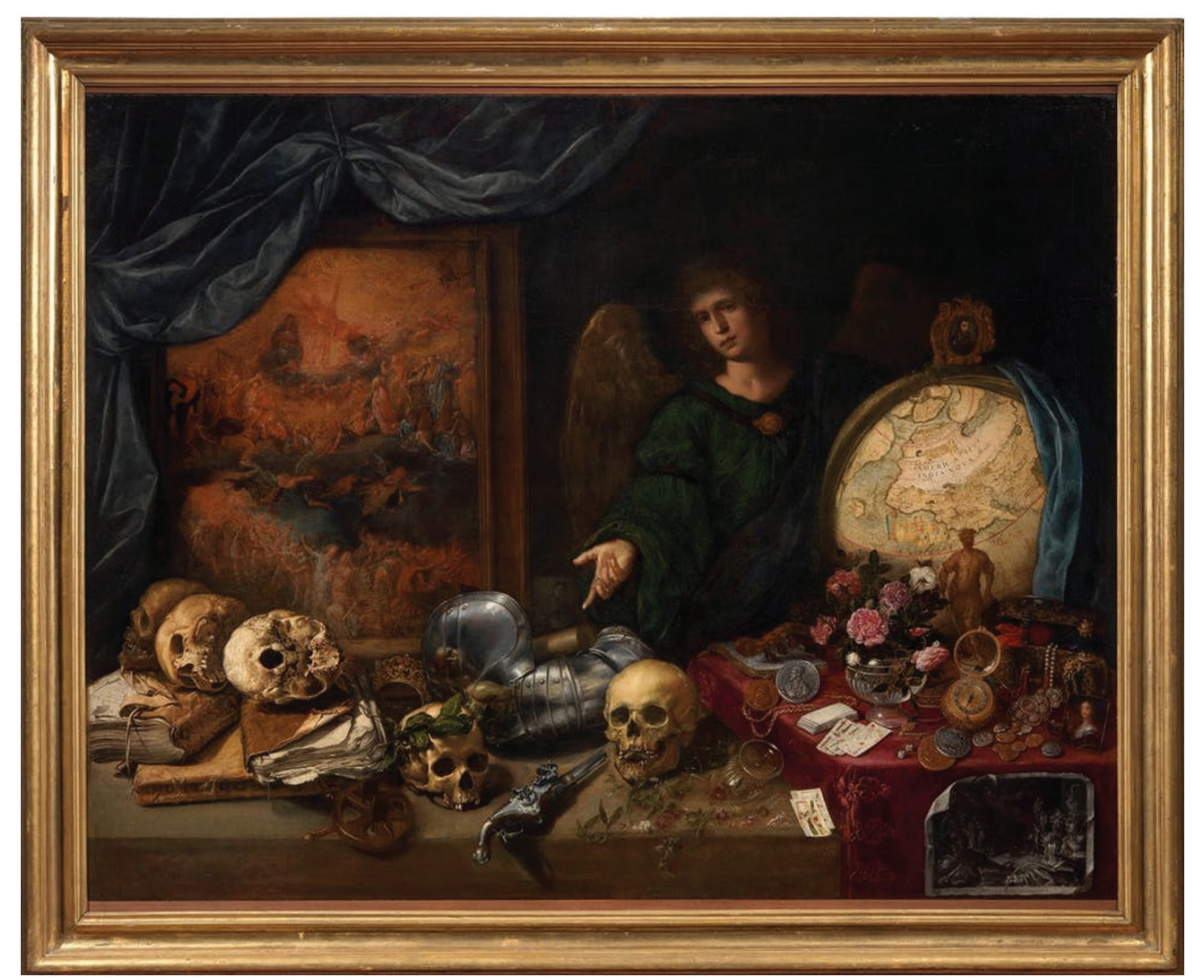

Fonte: Galeria Uffizi: https://www.uffizi.tt/en/artworks/pereda-vanitas. Consulta em julho/2020.

FIGURA 2. Madalena penitente, de Georges de La Tour (1640 ca.)

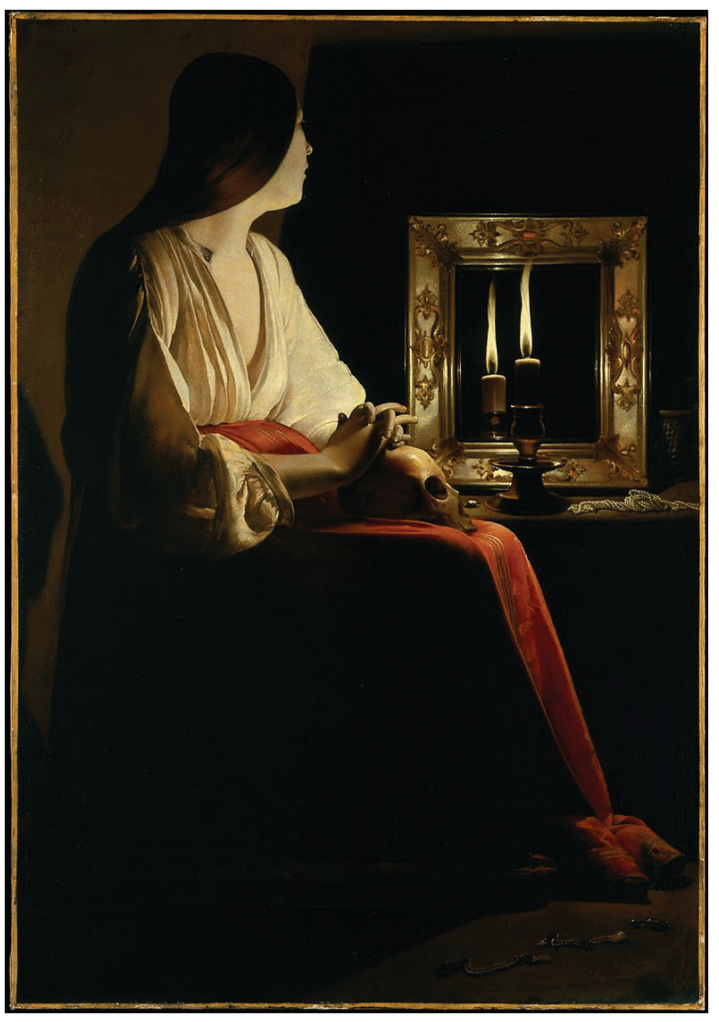

Fonte: Met Museum: https://www.metmuseum.org/art/collection/search/436839. Consulta em julho/2020. 
Para os propósitos da questão central aqui discutida, importa destacar o lugar de relevo dos sermões no âmbito da operação dessa "pastoral do medo". Nas populações em sua maioria iletradas, foi principalmente por meio da oralidade - portanto, pela pregação - que a aculturação cristã se realizou. Na breve e esclarecedora formulação de Jean-Claude Schmitt: "Maciça, sistemática, repetitiva, a nova pregação parece 'uma enorme máquina de converter as almas"' (1999, p. 144). Conforme sublinha o historiador das mentalidades Pierre Chanu (1976, p. 30), tendo em vista um enquadramento cristão, da idade antiga à época barroca foi-se passando de uma morte em que se perdia o conforto comunitário a uma morte pregação. Entende-se assim que a pedagogia católica da morte ensinasse a bem morrer e a bem viver, dada a crença no postulado de que a salvação eterna dependia da prática de obras meritórias.

Passo agora a um segundo ponto para discussão, tomando como guia a obra do crítico literário Louis van Delft (1993), que oferece pistas interessantes para a abordagem das letras seiscentistas e, mais especificamente, sobre a configuração da morte nesse período. Dentre tais pistas, destaca-se a constatação primordial de que a imagem do corpo é bastante difundida na cultura do século XVII, estando presente em diferentes áreas do conhecimento bem como nos discursos cotidianos. Reativada a partir do Renascimento, tal imagem se alimentou da tradição e, condensando a cosmovisão por meio de analogias e de correspondências, tão cara à época, conforme nos indicou Michel Foucault (1982, p. 33-67), foi aplicada a campos do saber tão diversos como a política, a eloquência, a cosmografia e a religião.

Um desdobramento dessa ênfase na imagem corporal, segundo Van Delft, é o paralelo entre anatomia moral e anatomia moralizada, igualmente relevante no período. Destaque-se que a metáfora anatômica conheceu um passado pouco glorioso, devido ao lento progresso dessa especialidade medical. No entanto, a partir do século XVI, época em que já se diagnosticou uma verdadeira "embriaguez anatômica" $(1989$, p. 2), ela se tornou mais presente, não apenas com a difusão de tal prática no âmbito do saber médico, mas também com a ampliação do espectro semântico da própria palavra, conforme veremos.

A “anatomia moralizada" - a formulação é de André Chastel (1955, p. 41) - refere-se à prática da anatomia propriamente dita, ou seja, à abertura e dissecação dos corpos, mas com uma sobrecodificação moralizadora, de base religiosa. Na época que nos ocupa, evidentemente pré-iluminista, os diversos campos do saber ainda não conquistaram sua autonomia, ocorrendo então interações e interferências entre medicina e philosophia moralis. Como efeito imediato disso, a anatomia sofria a contaminatio da moral, assim como na "anatomia moral" a cosmovisão patentemente católica era marcada pelo modelo anatômico.

Proponho um breve exame desta última, que funciona como uma espécie de pendant da anatomia moralizada. A expressão "moral anatomía del hombre" se encontra na narrativa El Criticón, do jesuíta espanhol Baltasar Gracián, cujo capítulo assim intitulado oferece uma descrição alegórica do corpo humano, em que cada parte constituiria a réplica, o resumo, ou o analogon das diversas partes da criação divina ${ }^{1}$.

\footnotetext{
${ }^{1}$ Para maiores desdobramentos da análise da narrativa de Gracián, cf. Oliveira, 2003, cap. 3.
} 
Se essa expressão verbal é de origem gracianesca, a prática da "anatomia moral" não se restringe a esse autor, tampouco ao contexto ibérico. Na França, no meio dos preciosos, a palavra "anatomia", em seu sentido figurado de "análise"2, é frequentemente empregada. Uma de suas primeiras ocorrências pode ser detectada em texto de Mlle. de Scudéry, no qual se lê a expressão "anatomia de um coração apaixonado", que corresponde à "descrição exata de todos os seus ciúmes, suas inquietudes, suas impaciências" (Citado em MONGRÉDIEN, 1963, p. 125). Desse modo, a ideia de se inspirar no modelo medical e anatômico para designar um exame minucioso, especialmente no estudo do homem e na descrição dos costumes sociais, estava no ar do tempo e seguia um modelo fornecido pela Antiguidade, ecoando a concepção estoica de que as paixões são as "doenças da alma", para as quais o filósofo moral fornece o "remédio".

Ora, assim como a ars medica, de que ela constitui a pedra angular, a anatomia repousa sobre uma ciência dos signos. Por sua vez, a anatomia moral, transposição do modelo anatômico para o campo da ética, não funciona sem pontos de ancoragem visáveis, sem índices externos reveladores do mundo interior. Em síntese, anatomizar é examinar até o momento em que se pode, com uma palavra, condensar, definir. E essa operação de nomeação é precisamente a caracterização; desse modo, anatomizar significa analisar até o momento em que se pode destacar e nomear o caráter. Eis aí uma visível passarela entre essa prática de dissecação do tecido moral e a pintura esquemática de tipos humanos, realizada pelos moralistas do século XVII.

Seguindo a antiga concepção semiológica do homem-microcosmo, que expressa uma visão unitária, global do homem no universo (Cf. FOUCAULT: 1981, p. 46-50), ainda presente na configuração epistemológica seiscentista, a anatomia moral concebe o ser humano sob a forma de correspondências: assim, o "interior do homem" - de modo geral, o "pequeno mundo" - só adquire sentido em relação ao resto da criação, ao macrocosmo. Que não reste qualquer dúvida: nas letras seiscentistas em exame, a doutrina cristã é realmente a matriz e o princípio dessa anatomia moral que disseca o homem para nele celebrar a imagem da divindade.

No tabuleiro teórico aqui construído, outro fator a considerar é o delicado e complexo jogo de forças que há muito pautava a relação entre a anatomia stricto sensu de um lado, a religião e a moral, de outro. De fato, a exploração do corpo humano suscitava os mesmos temores, as mesmas reticências que a do cosmo, e a suspeita que pesou sobre a anatomia não era diferente, em seu princípio, daquela que durante muito tempo entravou a busca da verdade na astronomia; consequentemente, a retórica presente no discurso sobre a anatomia encontrava-se sobredeterminada pela difícil relação de tal ciência com a auctoritas espiritual. Aliás, essa era a situação da própria medicina na primeira metade do século XVII: como viviam em um universo intelectual regido pela lei das similitudes, em que tudo se tocava e se interpenetrava, os médicos de então, para desenvolver uma política de boa vizinhança com o poder religioso dominante, frequentemente buscavam "apoiar as teses hipocráticas em citações da Bíblia” (ROGER, 1963, p. 30).

Em síntese, destaque-se que a prática da anatomia, lugar de uma relação de forças entre a Igreja e os homens de ciência, era alvo de uma política restritiva, controladora. Em uníssono

\footnotetext{
2 Em seu artigo "Anatomia da sátira", Adolfo Hansen esclarece o significado usual do termo no século XVII, 0 "de dialética ou divisão, decomposição ou análise de elementos constitutivos" (2011, p. 145)
} 
com Louis van Delft, pode-se afirmar que "o poder espiritual continua a manter um discurso moral, acima de tudo, acerca da anatomia. Paralelamente às figuras anatômicas, em contraponto, ele desdobra figuras retóricas" (1993, p. 192). Note-se, de passagem, que temos aí imbricados dois pontos centrais da configuração intelectual do século XVII, simultaneamente época da "revolução científica", conforme a concepção de R. Lenoble (1958) e "idade da eloquência", na designação de Marc Fumaroli (1980).

Dentre os diversos estratagemas persuasivos de moralização da anatomia nessa época, pode-se citar, por exemplo, o fato de, em certas universidades, as dissecações de corpos serem precedidas de música religiosa. Além disso, tal prática da anatomia, executada diante de um público bastante heterogêneo em grandes anfiteatros, apresenta semelhanças com a ação dramática, e pode ser associada ao amplo movimento de espetacularização da morte, promovido pela igreja contrarreformada, como meio de persuadir os fiéis quanto aos preceitos da ortodoxia católica, segundo observamos anteriormente. No entanto, a anatomia moralizada não se confina ao ambiente universitário: além dos professores dessa ciência, pintores, desenhistas, escritores colaboraram nessa empresa moralizadora. Numa época em que a autoridade de Quintiliano era hegemônica, a anatomia moralizada se alimentava de um mesmo arsenal de lugares e de figuras retóricas já limadas pelo uso, dentre as quais se destacava a imagem do esqueleto. Consideremo-la brevemente. Segundo parece evidente, uma parábola é subjacente a tal imagem: trata-se da revelação da verdade da aventura existencial, sintetizada nessa figura de impacto, que nos lembra de nossa finitude. Com grande eficácia persuasiva, a leitura do corpo anatomizado ou de uma parte expressiva deste, tal como o crânio, conduz sempre ao memento mori, como se percebe, por exemplo, na obra de diversos pintores seiscentistas, aqui já mencionados.

Mas que fique bem claro: no âmbito dessa arte de nos lembrar da morte, só de modo indireto, oblíquo, os artistas fazem concorrência aos pregadores. Desse grande poder de moralização de elementos de anatomia ou da própria morte, ninguém é mais consciente, no século XVII, do que aqueles que necessitam tratar do tema em função de seu ministério. É com razão que Didi-Huberman considera a morte o "paradigma principal do cristianismo", ocupando o centro de todas as suas operações imaginárias. Em suas próprias palavras, referindo-se à imitatio Christi: "a morte funciona como motor de todo desejo religioso, de toda catarse ritual, de toda transformação e, portanto, de toda figurabilidade. É que era necessário morrer para ser semelhante" (DIDI-HUBERMAN, 1990, p. 268). A esse respeito, cabe citar o relevante estudo de André Chastel sobre a "insolente fecundidade da morte barroca" (1955, p. 35), no qual o autor destaca a suntuosidade das cerimônias fúnebres seiscentistas, os castra doloris, com sua encenação duplamente grandiosa e macabra. Tal fenômeno deve ser relacionado às novas formas de espiritualidade contrarreformistas, com suas manifestações às vezes espetaculares de ascetismo macabro, amplamente evidenciadas nas pregações jesuíticas, que buscavam estimular, pela visão cruel da morte, o espírito de penitência dos fiéis. Vale lembrar também, com Piero Camporesi, o decisivo papel ocupado, no imaginário da época, pelas visões do inferno, que dominavam a cena cristã desde a Idade Média. Já o próprio Inácio de Loiola recomendava aos noviços criar uma simulação pessoal da cena infernal, conduzindo "os cinco sentidos a serem os testemunhos 
ativos da visita imaginária ao 'reino da dor" (CAMPORESI, 1989, p. 78). Assim, ao mesmo tempo em que se expõem a grandiosidade e a pompa das coisas terrenas, procura-se ressaltar sua transitoriedade, o que traz como corolário o medo da morte e o pavor do inferno, tão explorados nas pregações católicas para tentar obter a conversão dos ouvintes.

Um exemplo patente dessa atitude de moralização da morte nos á fornecido por Emilio Orozco (1988, p. 89-90) ao citar um célebre jesuíta espanhol que subia ao púlpito com uma caveira à qual aplicava, segundo o tema do sermão, ora uma peruca de médico, ora um barrete de magistrado, um elmo, e até mesmo uma coroa real. Jean Delumeau igualmente menciona alguns exemplos dessa prática na França, destacando que tal "pedagogia conheceu uma longa posteridade" (1983, p. 375). Nas tintas satíricas do poeta barroco Gregório de Matos, pode-se perceber a referência velada ao emprego do mesmo procedimento persuasivo no âmbito das pregações ocorridas no Brasil, em um poema dedicado a uma dama, que, por infortúnio, teve um foguete de São João estourando-lhe entre as pernas. Vejamos como, na deformação satírica, a recomendação bíblica do memento homo se metamorfoseia irônica e hereticamente:

\author{
Josefa, o que está melhor \\ ao vosso cono caveira \\ é dá-lo uma sexta-feira \\ de Quaresma a um Pregador: \\ porque ele com seu fervor, \\ e co' a caveira na mão \\ fará tão grande sermão, \\ que os homens por seu abono \\ ouvindo o memento cono \\ todos se arrependerão. (MATOS, 2013, vol. 4, p. 361)
}

Mesmo sem o emprego direto de recursos visuais extradiscursivos, destaca-se, em diversos sermões da época, a lapidação de imagens verbais extremamente persuasivas, tendo por finalidade "abrir um túmulo diante da corte", conforme os votos expressos no exórdio do famoso Sermão sobre a morte, do célebre bispo francês Jacques Bossuet (1970, p. 25). Na obra do padre Antônio Vieira, expoente máximo da pregação seiscentista luso-brasileira, encontra-se igualmente uma sutil exploração do poder de moralização da morte e do corpo morto, que se relaciona à grande corrente seiscentista da miseria hominis, fruto da "mentalidade patética" com a qual Robert Mandrou (1960, p. 898) caracterizou esse período.

Chegamos, por fim, ao foco central deste artigo, para o qual todas as observações anteriores convergem. Para abordar mais de perto o lugar do púlpito na difusão do conceito de morte propagado pelo catolicismo no século XVII, proponho um estudo de caso, analisando a renomada obra sermonística do jesuíta Antônio Vieira. Mais especificamente, examinarei a sua construção de um memento mori a partir da exploração do elemento mínimo a que se reduz o corpo morto; em outras palavras, trata-se de lembrar que o homem é pó e ao pó voltará, retomando o grande lugar-comum bíblico tão reciclado por pregadores e poetas da época. Esse tema escritural é desenvolvido nos três magistrais sermões escritos por Vieira para serem pregados na Quarta-Feira 
de Cinzas, os quais constituem, segundo Alcir Pécora (1994, p. 13), "uma verdadeira arte de morrer em uma perspectiva que hoje chamaríamos de barroca”.

Como se sabe, tal passagem bíblica (Gênesis, III, 19), que o sermonista português traduz por "sois pó, e em pó vos haveis de converter", refere o tempo que se segue ao pecado original, quando Deus condena o homem ao sustento da própria vida até que "retorne ao pó de que foi feito", sentença que acentua a desgraça da mortalidade e dos trabalhos que se abatem sobre a vida terrena nesse ângulo de visão. Para o mesmo tema, o jesuíta oferece três desenvolvimentos admiráveis e bastante diversos entre si, iluminando alguns dos principais lugares-comuns da parenética seiscentista, tais como morte, fugacidade do tempo, engano e vanitas.

$\mathrm{Na}$ impossibilidade de desenvolver uma análise aprofundada desses três sermões, proponho aqui uma breve leitura do primeiro deles, pregado em Roma, em 1672. Fiel à sua predileção pelos “pórticos espetaculares" (MENDES, 1989, p. 430), Vieira inicia a prédica com uma ponderação misteriosa, destacando o caráter paradoxal e obscuro da afirmação, presente na mencionada passagem das Escrituras Sagradas, de que, mesmo no presente, quando ainda está vivo, o homem seja pó. Leiamos:

Duas coisas prega hoje a Igreja a todos os mortais, ambas grandes, ambas tristes, ambas temerosas, ambas certas. Mas uma de tal maneira certa e evidente, que não é necessário entendimento para crer; outra de tal maneira certa e dificultosa, que nenhum entendimento basta para a alcançar. Uma é presente, outra futura: mas a futura veem-na os olhos, a presente não a alcança o entendimento. E que duas coisas enigmáticas são estas? [...] Pulvis es, et in pulverem reverteris: "Sois pó, e em pó vos haveis de converter". "Sois pó" é a presente; "em pó vos haveis de converter" é a futura. O pó futuro, o pó em que nos havemos de converter, veem-no os olhos; o pó presente, o pó que somos, nem os olhos o veem, nem o entendimento o alcança (VIEIRA, 2014, p. 98).

Para esclarecer o que ele denomina "dificultosa verdade" que parece negar o que veem os olhos, o jesuíta emprega inicialmente um método usual na argumentação retórica da época, baseado na reiterada postulação de perguntas, que expressariam as supostas dúvidas dos ouvintes e que são em seguida respondidas pelo sermonista. Por exemplo, à pergunta "Em que nos distinguimos logo os vivos dos mortos?", segue-se a pronta resposta, cuja inusitada formulação provoca surpresa, efeito sempre buscado pela arte retórica seiscentista: "Distinguimo-nos os vivos dos mortos, assim como se distingue o pó do pó. Os vivos são pó levantado, os mortos são pó caído; os vivos são pó que anda, os mortos são pó que jaz" (VIEIRA, 2014, p. 104).

Desse modo, após dificultar o enigma proposto inicialmente, em uma sucessão de perguntas que supõem dúvidas dos fiéis e que o tornam ainda mais oculto, o pregador propõe que a verdadeira substância do que vive não é dada pelo presente, mas pelo passado e pelo futuro. Em tal ângulo de visão, o presente seria um estado de aparência e engano entre um estado essencial revelado no passado e confirmado no futuro. $\mathrm{Na}$ análise de Alcir Pécora:

[...] a existência é sempre um caminho para a morte, que está na origem como no fim do homem, e que determina a sua natureza, mesmo que no presente a vida pareça preenchê-la completamente. A existência, portanto, conquanto tenha outras formas, nunca deixa de ser o pó para o qual tende. (1994, p. 31) 
Nesse sentido, se todos, vivos e mortos, são pó, o que os distingue, na postulação de Vieira, é apenas a imensa vaidade dos vivos, vício no qual se ancoram todos os enganos. Assim, o encaminhamento da argumentação construída no sermão desdobra a crítica escolástica da primeira parte do mencionado enigma em crítica moral e de costume, através do tema da vanitas, tão recorrente na época em foco.

Dessas ponderações misteriosas, o jesuíta passa à pastoral, ou seja, à proposição religiosa que tem por objetivo provocar mudanças no comportamento dos ouvintes. Propõe-se, então, a proferir dois mementos, isto é, duas orações de advertência aos fiéis: um dirigido aos vivos, outro aos mortos.

Aos vivos diz precisamente que se lembrem de que nada que chegarem a possuir poderá alterar a natureza revelada no fim da vida, uma vez que a vida e a fortuna que os animam são transitórias. Em sua engenhosa formulação:

[...] que se lembre o pó levantado que há de ser pó caído. Levanta-se o pó com o vento da vida, e muito mais com o vento da fortuna; mas lembre-se o pó que o vento da fortuna não pode durar mais que o vento da vida: e que pode durar muito menos, porque é mais inconstante. O vento da vida, por mais que cresça, nunca pode chegar a ser bonança; o vento da fortuna, se cresce, pode chegar a ser tempestade, e tão grande tempestade que se afogue nela o mesmo vento da vida. Pó levantado, lembra-te outra vez que hás de ser pó caído, e que tudo há de cair e ser pó contigo. (VIEIRA, 2014, p. 106)

Como estratégia eficaz para obter a persuasão, Vieira lança mão de um exemplum, apresentando a própria cidade de Roma, então considerada a cabeça da cristandade, como argumento evidente de sua tese, uma vez que os olhos descobrem a todo instante, sob o fausto contemporâneo dos palácios que a adornam, as ruínas do Império outrora tão poderoso. Em suas palavras: “Que coisa é Roma senão um sepulcro de si mesma?" (VIEIRA, 2014, p. 108). Tal destruição é interpretada em chave pedagógica, sendo moralizada em forma de memento mori aberto à meditação de todos: "Ordenou a Providência Divina que Roma fosse tantas vezes destruída, e depois reedificada sobre suas ruínas, para que a cabeça do mundo tivesse uma caveira em que se ver" (VIEIRA, 2014, p. 109).

Diagnosticados os problemas comuns a todos os homens, centrados na vaidade, na presunção e no engano que acometem o "pó levantado", aconselha-se aos fiéis uma terapêutica dupla, para prever os perigos e estabelecer o "verdadeiro juízo" acerca dos limites das coisas humanas: olhar para o futuro, através das profecias, e olhar para o passado, história de ruínas. Para figurar esse olhar que se volta para ambos os tempos, base da arte do desengano proposta em clave católica, o sermonista lança mão da alegoria escritural do espelho de Salomão: "dois espelhos recíprocos, que podemos chamar de tempo, em que se vê facilmente o que foi e o que há de ser. [...] Que é o que foi? Aquilo mesmo que há de ser. Que é o que há de ser? Aquilo mesmo que foi” (VIEIRA, 2014, p. 110). Desdobrando tal alegoria, Vieira configura o presente como um tempo composto desses dois reflexos - "o presente é o futuro do passado e o mesmo presente é o passado do futuro" (VIEIRA, 2014, p. 110) - ou seja, um tempo vazio, mera passagem, simulacro do tempo verdadeiro ainda por vir. 
Segue-se o memento aos mortos, produzindo-se uma notável mudança na direção argumentativa do sermão. O tema do desengano da vida e outros a ele associados, tais como o da fragilidade dos bens terrenos e da vanitas, dominantes no primeiro movimento, vão cedendo lugar ao exame dos efeitos definitivos, imortais, que decorrem das ações breves da existência. Nesse estágio, a morte não é apenas a realidade que põe termo às ilusões da vida mundana, mas uma espécie de sono, ainda mais fugaz do que elas, do qual os mortos despertarão para o Juízo Final. Em síntese, se o ser da vida é o pó, a morte, o ser da morte é a ressurreição, a imortalidade.

As observações anteriores possibilitam compreender um passo crucial da argumentação do jesuíta. Trata-se de apontar o duplo engano em que os homens incorrem com grande frequência, e que merece ser corrigido: primeiro, supor que a vida é imortal, isto é, tomar o mundo material por bem eterno; em seguida, supor que a morte é imortal e, assim, tomar os atos da vida, as obras boas ou más cometidas em sua duração, como não tendo efeitos para além dela. Na persuasiva formulação do sermonista:

A mim não me faz medo o pó que hei de ser, faz-me medo o que há de ser o pó. Eu não temo na morte a morte, temo a imortalidade; eu não temo hoje o dia de Cinza, temo hoje o dia de Páscoa: porque sei que hei de ressuscitar, porque sei que hei de viver para sempre, porque sei que me espera uma eternidade, ou no Céu, ou no inferno. (VIEIRA, 2014, p. 112)

Na parte final do memento aos mortos, o pregador enfatiza o caráter terrível desse segundo engano: assim, o temor mais justificado não é o que se sente diante da possibilidade de perder a vida, mas diante da possibilidade de tê-la condenada, de arrastá-la consigo infinitamente no inferno. Fiel aos preceitos inacianos, a arte de morrer de Antônio Vieira ganha aqui a veemência do terror, pathos recorrente nas pregações contrarreformistas, segundo já tivemos a ocasião de comentar:

A morte tem duas portas. [...] Uma porta de vidro, por onde se sai da vida; outra porta de diamante, por onde se entra à eternidade. Entre estas duas portas se acha subitamente um homem no instante da morte, sem poder tornar atrás, nem parar, nem fugir, nem dilatar, senão entrar para onde não sabe, e para sempre. Oh que transe tão apertado! Oh que passo tão estreito! Oh que momento tão terrível! Aristóteles disse que, entre todas as coisas terríveis, a mais terrível é a morte. Disse bem; mas não entendeu o que disse. Não é terrível a morte pela vida que acaba, senão pela eternidade que começa. Não é terrível a porta por onde se sai; a terrível é a porta por onde se entra. Se olhais para cima, uma escada que chega até o Céu; se olhais para baixo, um precipício que vai parar no Inferno; [...]. (VIEIRA, 2014, p. 114)

Portanto, para que não se tome a escada descendente, é importante meditar continuamente sobre a morte ainda em vida, preparando-se para ela. Assim, o sermão se encerra com um ultimatum ao ouvinte, destacando o papel decisivo das decisões tomadas durante a vida sobre o destino post mortem. Desse ponto de vista, e perfeitamente de acordo com o que se tornou comum ao pensamento contrarreformista, essa arte de morrer de Vieira opõe-se à tradição das artes moriendi, populares desde o século XIV, fundadas na preparação para a "última prova" que seria apresentada no quarto do moribundo, quando este poderia escapar do inferno ou mesmo 
do purgatório mediante a confissão dos pecados e uma demonstração genuína de arrependimento. Em chave inaciana, não é no leito de morte que se decide a salvação ou a condenação do cristão, mas nas suas escolhas e ações do presente (Cf. PÉCORA, 1994, p. 35).

Para finalizar a análise do sermão, é importante ressaltar que, nessa primeira pregação da Quarta-Feira de Cinzas, a pastoral mortuária de Vieira não é desconsoladora; bem de acordo com as perspectivas pós-tridentinas, a morte está inscrita numa perspectiva fundamentalmente salvífica. A esse respeito, cabe citar a esclarecedora síntese de Alcir Pécora: "Com Vieira, é a própria vertigem gerada pelo seu discurso, a repor a imaginação violenta da última hora, que assinala ao ouvinte a urgência da disposição capaz de fazê-lo romper a cadeia das más eleições que o arrastam, vivo, para a condenação eterna" (PÉCORA, 1994, p. 36). Na impossibilidade de desenvolver a análise dos outros dois sermões que o jesuíta dedicou a esse tema, dado o escopo deste artigo, deixo um convite aos leitores para que os leiam, verificando que cada um deles apresenta nuances diversas e desdobramentos inauditos ao mencionado excerto bíblico que lhes serve de mote.

Para que este texto não se estenda demasiadamente, convém tentar agora, em um procedimento, aliás, bem caro às práticas textuais seiscentistas, "recolher" os principais elementos "disseminados" nas etapas aqui percorridas. Sem qualquer pretensão de atar cerradamente todos os fios e não querendo incorrer na mesma forma de "dinamismo apático" (HOCKE, 1974, p. 213) com que já se caracterizou o estilo barroco, tentarei diagramar, em breves traços, as principais linhas de força do campo problemático aqui construído e que ora se mostra em seus diversos ângulos.

Em cada época, como se sabe, a Igreja lê o Evangelho através de suas preocupações do momento, sua antropologia - que varia - e seus projetos pastorais. Durante o período que estudamos, no qual o objetivo maior da ortodoxia católica era o de "culpabilizar para salvar", dentre os temas traumatizantes da "pastoral do medo" então dominante encontramos evidentemente a morte, cuja exploração atingiu seu ápice no século XVII.

Reiteremos com Jean Delumeau (1983, p. 127) que a origem dessa concepção cristã sobre a morte se localiza na reflexão ascética dos monges inteiramente voltados para o além e que queriam se convencer - e persuadir os outros - do caráter nefasto das ilusões deste mundo. Esse discurso eclesiástico foi difundido posteriormente fora dos conventos pela pregação e pela iconografia, isto é, por todos os meios empregados por uma "pastoral do medo". Esta se inquietava com o aumento do luxo e da crescente aspiração aos bens terrestres de uma civilização que, ao menos em seus níveis sociais mais elevados, se afastava da indigência e tendia para mais conforto. A insistência no macabro e a espetacularização da morte que se verificam nas práticas sociais dos séculos XVI e XVII, no rastro do contemptus mundi, se inseriam, então, na lógica de um vasto empreendimento de culpabilização orientado para a salvação no além.

Importa igualmente destacar que a difusão do medo do Deus juiz, com todas as suas consequências, no nível das massas católicas recorreu, por vezes, a uma tática aterrorizadora que reforçou ainda mais o poder clerical. Em outras palavras: para comunicar às massas, a pastoral busca os meios mais próprios para impressionar, utilizando "os estratagemas capazes de reforçar a autoridade dos sermonistas e de tornar crível essa mistura de culpabilização, de ameaças e de consolações que constituiu, durante séculos, o tecido mais usual da pregação" (DELUMEAU: 1983, p. 369). 
Em síntese, como se observou no sermão de Antônio Vieira aqui discutido, os jesuítas, seguindo os passos dos Exercícios Espirituais de seu Patriarca, Inácio de Loyola, tendiam a enxergar na morte uma fertilíssima fonte de imaginação, que era também a mais importante ocasião de uma consciência do desengano dos bens mundanos, traduzindo-se num ato de conversão em favor de uma vida racional e pia. Consoante busquei destacar, em tal perspectiva, o que existe na vida é apenas engano e vaidade, uma vez que a existência caminha invariavelmente para a morte, onde tudo se desfaz: riquezas, vaidades, glórias. Viver, então, seria se preparar para morrer, por isso é inútil correr atrás dos enganos do mundo, que de nada adiantariam na hora do Juízo Final. Cito novamente as palavras daquele que Fernando Pessoa denominou de "o Imperador da língua portuguesa", no sermão aqui comentado:

Esta nossa chamada vida, não é mais que um círculo que fazemos de pó a pó: do pó que fomos ao pó que havemos de ser. Uns fazem o círculo maior, outros menor, outros mais pequeno, outros mínimo: de utero translatus ad tumulum: mas ou o caminho seja largo, ou breve, ou brevíssimo, como é círculo de pó a pó, sempre e em qualquer tempo da vida somos pó. (VIEIRA, 2014, p. 103)

Para concluir, retorno à voz do poeta Gregório de Matos, presente na abertura deste texto, em soneto que igualmente discute a questão da moralização da morte no âmbito do pensamento católico seiscentista:

Que és terra, Homem, e em terra hás de tornar-te,

Te lembra hoje Deus por sua Igreja,

De pó te faz espelho, em que se veja

A vil matéria, de que quis formar-te. (MATOS, 2014, vol. 1, p, 122)

\section{REFERÊNCIAS}

ARIĖS, Philippe. História da morte no Ocidente. Trad. de Priscila Viana de Siqueira. Rio de Janeiro: Francisco Alves, 1977.

BOSSUET, Jacques. Sermon sur la mort . Paris: Garnier-Flammarion, 1970.

CAMPORESI, Piero. L 'Enfer et le phantasme de I 'hostie, une théologie baroque. Paris: Hachette, 1989.

CHANU, Pierre. Mourir à Paris (XVIe-XVIIIe siècles. In: Annales Économies, Sociétés, Civilisations, 31 anée, $n^{\circ}$ 1, janvier-février. Paris: Armand Colin, 1976.

CHASTEL, André. Le baroque et la mort In: CASTELLI, Enrico (org.). Retorica e Barocco. Atti del III Congresso Internazionale di Studi Umanistici. Roma: Fratelli Bocca Editori, 1955.

DELUMEAU, Jean. Le péché et la peur : la culpabilisation en Occident XIIIe-XVIIIe siècles. Paris: Fayard, 1983.

DIDI-HUBERMAN, Georges. Devant I’ image. Paris: Minuit, 1990.

FOUCAULT, Michel. As palavras e as coisas. 2. ed. São Paulo: Martins Fontes, 1981. 
FUMAROLI, Marc. Lâge de I'éloquence. Rhétorique et «res literaria» de la Renaissance au seuil de l'époque classique. Genebra: Droz, 1980.

HANSEN, João Adolfo. Anatomia da sátira. In: VIEIRA, Brunno V.G \& THAMOS, Márcio (org.). Permanência clássica: visões contemporâneas da Antiguidade greco-romana. São Paulo: Escrituras, 2011. p. 145-169.

HOCKE, Gustav. Maneirismo: o mundo como labirinto. São Paulo: Perspectiva, 1974.

LENOBLE, R. La révolution sicentifique du XVIIe siècle. In: TATON, R. (dir.) Histoire générale des sciences, t.II. Paris: Presses Universitaires de France, 1958. p. 43-61.

MÂLE, Émile. Lart religieux après le Concile de Trente: étude sur l'iconographie de la fin du XVIe siècle, du XVIIe, du XVIIIe siècle, Italie-France-Espagne-Flanders. Paris: A. Colin, 1932.

MANDROU, Robert. Le baroque européen: mentalité pathétique et révolution sociale. Annales. Economies, Sociétés, Civilisations, n. 5, p. 76-92, set./out. 1960.

MATOS, Gregório de. Poemas atribuídos: Códice Asensio-Cunha. 4 vol. Edição e estudo de João Adolfo Hansen e Marcello Moreira. Belo Horizonte: Autêntica, 2013.

MENDES, Margarida V. A oratória barroca de Vieira. Lisboa: Editorial Caminho,1989.

MONGRÉDIEN, G. (org.) Les Précieux et les précieuses. Paris: Mercure de France, 1963.

OLIVEIRA, Ana Lúcia M. de. Por quem os signos dobram: uma abordagem das letras jesuíticas. Rio de Janeiro: EdUERJ, 2003.

OROZCO, Emilio. Manierismo y Barroco. 4. ed. Madrid: Cátedra, 1988.

PÉCORA, Alcir. A arte de morrer: os sermões de quarta-feira de cinzas de Antônio Vieira. São Paulo: Nova Alexandria, 1994.

ROGER, Jacques. Esprit médical et esprit scientifique dans la première moitié du XVII siècle. In: ROGER, Jacques. Les Sciences de la vie dans la pensée française du XVII siècle. Paris: Colin, 1963. p. 23-49.

SCHMITT, Jean-Claude. Os vivos e os mortos na sociedade medieval. São Paulo: Companhia das Letras, 1999.

VAN DELFT, Louis. Littérature et anthropologie: le caractère á lâge classique. Paris: Presses Universitaires de France, 1993.

VIEIRA, Antônio. Sermão da Sexagésima e Sermões da Quaresma. In: Obra completa padre António Vieira, tomo II, vol. II. Dir. José Eduardo Franco e Pedro Calafate. Lisboa: Círculo de Leitores, 2014.

\section{REFERÊNCIAS ICONOGRÁFICAS}

LA TOUR, Georges. Madalena penitente. Pintura a óleo, 1640 ca. Domínio público. Disponível em: https:// www.metmuseum.org/art/collection/search/436839. Última consulta julho/2020.

PEREDA, Antonio de. Vanitas. Pintura a óleo. 1670 ca. Domínio público. https://www.uffizi.it/en/artworks/ pereda-vanitas. Última consulta em julho/2020. 